KEYNOTE ADDRESS

George Mason University

AGEP Advanced Policy Institute on Financial Services Regulation

March 10, 2011

\title{
Identifying and Managing Systemic Risk: An Assessment of Our Progress ${ }^{1}$
}

Steven L. Schwarcz ${ }^{2}$

1 (c) 2011 by Steven L. Schwarcz.

${ }^{2}$ Stanley A. Star Professor of Law \& Business, Duke University School of Law; Founding/Co-Academic Director, Duke Global Capital Markets Center. E-mail: schwarcz@law.duke.edu. I thank Kenneth Anderson for helpful comments on a draft of this address. 
Although banks and other financial institutions are important sources of capital, and although a chain of bank failures remains an important symbol of systemic risk, the ongoing trend towards disintermediation-or enabling companies to access the ultimate source of funds, the capital (i.e., financial) markets, without going through banks or other financial intermediaries - is making these failures less critical than in the past. Companies today are able to obtain most of their financing through financial markets without the use of intermediaries. As a result, financial markets themselves are increasingly central to any examination of systemic risk.

This has been dramatically illustrated by the recent financial crisis. Although the bankruptcy of Lehman Brothers got the initial headlines, the trigger of the crisis was the collapse of the market for mortgage-backed securities. A significant number of these securities were backed by subprime (or risky) home mortgages, which were expected to be refinanced through home appreciation. When home prices stopped appreciating, the borrowers could not refinance. In many cases, they defaulted.

These defaults in turn caused substantial amounts of investment-grade rated securities backed by these mortgages to be downgraded and, in some cases, to default. Investors began losing confidence in these and other rated securities, and their market prices started falling.

Lehman Brothers, which held large amounts of mortgage-backed securities, was particularly exposed. Firms that had been doing business with Lehman—its ‘counterparties’—began demanding additional safeguards, 
which Lehman could not provide. As a result, absent a government bailout, Lehman could not continue doing business.

The refusal of the Government to save Lehman Brothers, and Lehman's resulting bankruptcy, added to this cascade. Securities markets became so panicked that even the short-term commercial paper market virtually shut down, and the market prices of mortgage-backed securities collapsed substantially below the intrinsic value of the mortgage assets underlying those securities. ${ }^{3}$

The collapse became a death spiral as banks and other financial institutions holding mortgage-backed securities had to write down their value under "mark-to-market" accounting rules. This caused these firms to appear more financially risky, in turn triggering widespread concern over counterparty risk. The high leverage of many of these firms effectively required fire-sales of assets, exacerbating the fall.

Although the Dodd-Frank Act prescribes many steps to attempt to prevent another financial crisis, most of these steps focus on banks and other financial institutions, not on financial markets. Such a limited focus worked well when banks and financial institutions were the primary source of corporate financing. But the financial crisis reveals that this focus is insufficient now that companies obtain much of their financing directly through financial markets—such as through securitization financing.

\footnotetext{
${ }^{3}$ For example, in July 2008 I was an expert in the Orion Finance SIV case in the English High Court of Justice. Orion's mortgage-backed securities had a market value of around
} 
Financial institutions and financial markets can both be triggers, and also transmitters, of systemic risk.

\section{ANALYSIS}

So how should we regulate systemic risk? The primary if not sole justification for regulating financial risk is maximizing economic efficiency. Because systemic risk is a form of financial risk, efficiency should be a central goal in its regulation.

But systemic risk creates an added regulatory dimension: without regulation, the externalities - harm to third parties — would not be prevented or internalized because systemic risk is a risk to the financial system itself. Market participants are motivated to protect themselves, but they are not as directly motivated to protect the system as a whole.

As a result, there is a type of "tragedy of the commons," a collective action problem in which the benefits of exploiting finite capital resources accrue to individual market participants, each of whom is motivated to maximize use of the resources, whereas the costs of exploitation, which affect the real economy, are distributed among an even wider class of persons. ${ }^{4}$ Any regulation of systemic risk thus should focus not only on traditional efficiency but also on stability of the financial system. 
In examining regulatory approaches to systemic risk, one should also take into account the costs of regulation. There are direct costs, such as hiring government employees to monitor and enforce the regulations. But more importantly there can be indirect costs, such as overregulation that stifles innovation and competitiveness.

Subject to that caveat, consider a range of possible regulatory approaches, aimed at making the financial system more efficient and stable, as a means of assessing Dodd-Frank.

Averting Panics. The ideal regulatory approach would focus on eliminating the risk of systemic collapse from the outset. This goal could be substantially achieved by preventing financial panics, since they are often the triggers that commence a chain of failures. The financial crisis itself, for example, was initially triggered by financial market panic. But any regulation aimed at preventing panics that trigger systemic risk would almost certainly fail to anticipate all the causes of the panics. Furthermore, even when identified, panics cannot always be averted easily because investors are not always rational.

Requiring Increased Disclosure. Another potential regulatory approach is to improve disclosure. Disclosing risks traditionally has been viewed, at least under U.S. securities law, as the primary market-regulatory mechanism. Dodd-Frank puts great stock in the idea of improving disclosure.

\footnotetext{
${ }^{4}$ I originally introduced this concept in Systemic Risk, 97 GEORGETOWN LAW JOURNAL 193 (2008), available at http://ssrn.com/abstract_id=1008326.
} 
Disclosure works by reducing, if not eliminating, asymmetric information among market players, making the risks transparent to all. In the context of systemic risk, however, individual market participants who fully understand that risk will be motivated to protect themselves but not necessarily the system as a whole. As my tragedy-of-the-commons observation suggests, a market participant may well decide to engage in a profitable transaction even though doing so could increase systemic risk, since much of the harm from a possible systemic collapse would be externalized.

Furthermore, the efficacy of disclosure is limited by the increasing complexity of transactions and markets - complexity being, I believe, the greatest $21^{\text {st }}$ Century challenge for our financial system. In the financial crisis, for example, there is little question that virtually everything was disclosed regarding the complex mortgage-backed securities. Yet many institutional investors bought these securities based primarily on their ratings, without fully understanding them.

There are at least four reasons why disclosure failed:

(i) Investors overrelied on heuristics such as rating-agency ratings. Dodd-Frank attempts to fix this problem by focusing on ratings, not on investors. However, the actions of S\&P and Moody's arguably met the Act's requirements, had those requirements applied during the financial crisis. The real problem, I believe, is not rating agency failure but investor complacency. Because human nature can’t be easily changed, I'm unsure- 
and Dodd-Frank does not address—how investor complacency can be remedied.

(ii) Investors followed the herd in their investment choices. Again, this is an implacable problem of investor complacency.

(iii) Conflicts of interest were driven by short-term management compensation schemes, especially for technically sophisticated secondary managers. ${ }^{5}$ For example, as the VaR, or value-at-risk, model for measuring investment-portfolio risk became more accepted, financial firms began compensating secondary managers not only for generating profits but also for generating profits with low risks, as measured by VaR. Secondary managers therefore turned to investment products with low VaR risk profile, like credit-defaults swaps that generate small gains but only rarely have losses. The managers knew, but did not always explain to their seniors, that any losses that might eventually occur would be huge.

This is an intra-firm conflict, quite unlike the traditional focus of scholars and politicians on conflicts between senior executives and shareholders. Dodd-Frank attempts to fix the traditional type of conflict but completely ignores the problem of secondary-management conflicts. ${ }^{6}$

\footnotetext{
${ }^{5}$ See Conflicts and Financial Collapse: The Problem of Secondary-Management Agency Costs, 26 YALE J. ON REG. 457 (2009), available at http://ssrn.com/abstract_id=1322536. ${ }^{6}$ Dodd-Frank's attempt to fix the traditional conflict might actually backfire; recent research by UCLA Prof. Iman Anabtawi suggests that shareholders, even more than senior executives, want companies to take risks.
} 
(iv) The retention by underwriters of residual risk portions may have fostered false confidence in buyers, in effect creating a mutual misunderstanding. Ironically, this could be exacerbated in the future by Dodd-Frank's requirement that sellers of securitization products retain a minimum unhedged position in each class of products they sell.

Imposing Financial-Exposure Limits. The failure of one or more large and interconnected institutions could create defaults large enough to de-stabilize other highly-leveraged investors, increasing the likelihood of a systemic market meltdown. This suggests another possible approach to regulation: placing limits on an institution's financial exposure.

These limits could be imposed in various ways, such as (i) limiting an institution’s leverage; (ii) limiting an institution's right to make risky investments; and (iii) limiting amounts of inter-institution exposure. Consider each in turn.

(i) Limiting an institution's leverage could reduce the risk that an institution fails in the first place. It also could reduce the likelihood of transmitting financial contagion between institutions. But limiting leverage can create significant costs. Some leverage is good, and there is no optimal across-the-board amount of leverage that is right for every institution. The Dodd-Frank Act, however, directs the Federal Reserve to set "prudential” capital standards for certain large financial institutions, ${ }^{7}$ including a maximum debt-to-equity ratio of 15:1. 
(ii) Limiting an institution's right to make investments is a highly paternalistic approach, substituting a blanket regulatory prescription for a firm's own business judgment. One should be highly skeptical of any rule that attempts to protect a sophisticated financial institution from itself. Dodd-Frank implementation of the Volker Rule, however, attempts to do precisely that by limiting the ability of banks and certain other financial institutions to engage in "proprietary trading”-essentially investing in securities for their own account. ${ }^{8}$

(iii) Inter-institution financial-exposure limits would facilitate stability by diversifying risk, in effect by reducing the losses of any given contractual counterparty and thus the likelihood that such losses would cause the counterparty to fail. Limits also might reduce the urgency, and hence the panic, that contractual counterparties feel about closing out their positions.

This approach already applies to banks through lending limits, which restrict the amount of bank exposure to any given customer's risk. Its application beyond banks to other financial institutions is potentially appealing given the increasing blurring of lines between banks and non-bank financial institutions and the high volumes of financial assets circulating among non-bank financial entities.

It is questionable, though, whether the government should impose financial exposure limits on large financial institutions. These institutions

\footnotetext{
${ }^{7}$ Banks are already subject to the Basle capital requirements.

${ }^{8}$ I could, however, see the merit of a more nuanced rule limiting proprietary trading keyed into the tragedy-of-the-commons problem.
} 
already try to protect themselves through risk management and risk mitigation. The financial crisis has raised questions, however, whether conflicts of interest among managers and other failures can undermine institutional risk management. Dodd-Frank addresses this problem by requiring many large public financial firms to establish risk committees, including at least one risk-management expert, to be responsible for enterprise-wide risk management oversight.

Limiting Financial Institution Size. This is related to financial exposure limits; but here there is also the moral-hazard potential that institutions who believe they are "too big to fail" will engage in risky projects. There is, however, no clear evidence of such risky behavior, and financial institutional losses in the recent financial crisis can be explained by other reasons.

I would caution against artificially limiting financial institution size. Size should be governed by the economies of scale and scope needed for institutions to successfully compete, domestically and abroad—so long as that size is manageable.

We should watch out, however, for institutions that increase their size, especially by acquisition of other institutions, primarily to satisfy senior management egos. Dodd-Frank indirectly addresses this concern by (at least weakly) linking senior executive compensation to long-term results—for example, requiring stock exchanges to adopt standards whereby listed companies implement policies to recoup senior executive compensation in the event of an accounting restatement. 
Ensuring Liquidity. Ensuring liquidity could facilitate stability in two ways: by providing liquidity to prevent financial institutions from defaulting, and by providing liquidity to financial markets as necessary to keep them functioning.

The Federal Reserve Bank has had the role (under §13(3) of the Federal Reserve Act) of providing liquidity to prevent banks and other financial institutions from defaulting, by acting as a lender of last resort. Acting as a lender of last resort to institutions can be costly, however. By providing a lifeline, a lender of last resort can at least theoretically foster moral hazard by encouraging financial institutions-especially those that believe they are "too big to fail"- to be fiscally reckless. It also can shift costs to taxpayers since loans made to institutions will not be repaid if the institutions eventually fail.

For these reasons, the Dodd-Frank Act sharply limits the power of the Federal Reserve to make emergency loans to individual or insolvent financial institutions. That categorical limitation appears somewhat excessive, though; a lender of last resort can be an important safeguard if it acts judiciously.

One way that Dodd-Frank attempts to avoid the need to make emergency loans is by requiring banks and-to the extent designated as “systemically important," other financial firms - to be subject to a range of capital, leverage, and liquidity requirements and periodic "stress testing.” It also requires these entities to submit a resolution plan (a "living will") that 
sets forth how, if it fails, the firm would wind down in a way that minimizes systemic impact. The intention is to prevent a failure and, if a failure occurs, to mitigate the need for emergency loans by allowing the firm to fail. The ultimate question, though, will be whether the ex ante plan matches the ex post reality.

Regardless of how one views a lender of last resort to financial institutions, the financial crisis has shown that, in an era of disintermediation, more attention needs to be focused on providing liquidity to financial markets as necessary to keep them functioning. This approach should also be less costly than lending to institutions. A market liquidity provider of last resort, especially if it acts at the outset of a market panic, can profitably invest in securities at a deep discount from the market price and still provide a "floor" to how low the market will drop. Buying at a deep discount will mitigate moral hazard and also make it likely that the market liquidity provider will be repaid.

Reducing Complexity. An obvious way to address complexity would be to require investments and other financial products to be more standardized, so market participants do not need to engage in as much due diligence.

One of the goals of Dodd-Frank is to standardize more derivatives transactions. To this end, the Act requires many derivatives to be cleared 
through clearinghouses, which generally require a high degree of standardization in the derivatives they clear. ${ }^{9}$

The overall economic impact of standardization is unclear, though, because standardization can interfere with the ability of parties to achieve the efficiencies that arise when firms issue securities tailored to particular needs of investors.

\section{RECOMMENDATIONS}

I would recommend at least three regulatory initiatives that go beyond Dodd-Frank: (1) require that managers, including secondary managers, of financial institutions be compensated based more on long-term firm performance; (2) establish a market liquidity provider of last resort; (3) require financial institutions of systemic significance to contribute to a fund that would be used to mitigate systemic externalities.

Let me expand on the latter two recommendations, which may not be obvious on their face.

A market liquidity provider of last resort would have the best chance of minimizing a systemic collapse under any number of circumstances. Chaos theory supports the concept of a market liquidity provider of last resort. In complex engineering systems, as in complex financial markets,

\footnotetext{
${ }^{9}$ This can become a little circular, though, because Dodd-Frank includes an exception for derivatives that a clearinghouse will not accept for clearing. Query also the extent to
} 
failures are inevitable. Therefore modularity is needed to break the transmission of these failures and limit their systemic consequences. Such a mechanism usually exists (or should exist) for banks, in the form of a liquidity provider of last resort; we also need this type of mechanism for complex financial markets. ${ }^{10}$

Recent experience in the financial crisis supports establishment of a market liquidity provider of last resort. In response to the collapse of the commercial paper market, the Federal Reserve created the Commercial Paper Funding Facility (“CPFF”) to act as a lender of last resort for that market, with the goal of addressing "temporary liquidity distortions" by purchasing commercial paper from highly rated issuers that could not otherwise sell their paper. ${ }^{11}$ The CPFF apparently helped to stabilize the commercial paper market. ${ }^{12}$

One might ask why, if a market liquidity provider of last resort can invest at a deep discount to stabilize markets and still make money, private investors won't also do so, thereby eliminating the need for some sort of governmental market liquidity provider. One answer is that individuals at investing firms will not want to jeopardize their reputations (and jobs) by causing their firms to invest at a time when other investors have abandoned the market. Another answer is that private investors usually want to buy and

which the clearinghouse requirement will inadvertently concentrate systemic risk in the clearinghouses themselves.

10 See Regulating Complexity in Financial Markets, 87 WASHINGTON UNIVERSITY LAW REVIEW 211 (2009/2010), available at http://ssrn.com/abstract_id=1240863.

${ }^{11}$ See Tobias Adrian, Karin Kimbrough, \& Dina Marchioni, 'The Federal Reserve's Commercial Paper Funding Facility,” FRBNY Econ. Policy Rev. (forthcoming). 
sell securities, not waiting for their maturities, whereas a market liquidity provider of last resort should be able to wait until maturity, if necessary.

My third recommendation - to require financial institutions of systemic significance to contribute to a systemic risk fund-responds to the tragedy-of-the-commons problem by helping to mitigate systemic externalities. This type of approach was originally in the Dodd-Frank Act, but it was taken out before enactment because of opposition by politicians who believed (in my opinion, wrongly) that it would increase moral hazard by institutionalizing bailouts.

A privately-funded systemic risk fund not only can mitigate systemic externalities but also can help minimize the potential for risky behavior caused by institutions that believe they are too big to fail. The too-big-to-fail problem is effectively an externality imposed on government (and ultimately taxpayers) by an institution engaging in such risky behavior. A privatelyfunded systemic risk fund would help to internalize that externality. Furthermore, the ability of government to require additional contributions to this type of fund should motivate contributors to the fund to monitor each other to reduce the potential for such risky behavior.

Recently, the European Commission has been toying with the idea of a systemic risk fund in connection with its proposal to tax the financial sector. Although the ultimate use of the tax revenues is currently unresolved, news reports indicate that an originally contemplated use was a systemic risk

${ }^{12} I d$. at 11 (concluding that " $[\mathrm{t}]$ he CPFF indeed had a stabilizing effect on the commercial paper market”). 
fund. The IMF also appears to be using the European Commission tax proposal as a platform to announce that 'new taxes on banks [are] needed to provide an insurance fund for future financial meltdowns and to curb excessive risktaking.' 13

The European Commission recognizes that to avoid making the EU financial sector uncompetitive, any tax on the financial sector should be applied in all financial centres. This illustrates a broader principle: because financial markets and institutions increasingly cross sovereign borders, any regulatory approaches must be designed to work in an international context. The Dodd-Frank Act does not, however, fully come to grips with how the U.S. financial regulatory framework should operate, or even fit, as part of a global financial regulatory framework.

\section{CONCLUSION}

We have made some, but not nearly enough, progress in identifying and managing systemic risk. Hopefully my talk this evening has illustrated some of the progress, and some of the limitations.

Being a political response, Dodd-Frank consists largely of politically targeted responses to the recent financial crisis, at times looking for villains (whether or not they exist) who caused the crisis. To be most effective, however, financial regulation must be situated within an analytical framework that realistically explains how systemic risk is transmitted and

\footnotetext{
${ }^{13}$ Larry Elliott \& Jill Treanor, IMF: Supervise and Tax Banks or Risk Crisis, THE GUARDIAN, Oct. 8, 2010, at 25 (London-final ed.) (paraphrasing an announcement by IMF Managing Director Dominique Strauss-Kahn).
} 
why free-market factors do not limit that transmission. ${ }^{14}$ The tragedy of the commons, for example, is certainly part of that explanation. ${ }^{15}$

The Dodd-Frank Act nonetheless has the potential to ultimately reach beyond politically targeted responses. The Act delegates much of the regulatory details to administrative rulemaking, in many cases after the relevant government agencies engage in further study. Perhaps even more significantly, the Act creates a Financial Stability Oversight Council, part of whose mission is to monitor and identify potential systemic threats in order to find regulatory gaps. The Council will be aided in this task by a newlycreated and, we all should hope, nonpartisan Office of Financial Research.

Thank you.

\footnotetext{
${ }^{14}$ See, e.g., Regulating Systemic Risk: Towards an Analytical Framework, forthcoming in 86 Notre DAME LAW REVIEW, issue no. 4 (Spring 2011), available at http://ssrn.com/abstract=1735025.

${ }^{15}$ Indeed, I have argued that the failures giving rise to the recent financial crisis can be attributed conceptually to at least four market imperfections: conflicts of interest, complacency of investors and other market participants, complexity of financial markets and of the securities traded therein, and the tragedy of the commons. See Understanding the Subprime Financial Crisis, 60 S. C. L. REV. 549 (2009). My talk this evening references all of these failures.
} 